\title{
Effect of diallyl disulphide on glucose utilization in isolated alloxan diabetic liver.
}

\author{
Prashanthkumar Goudappala ${ }^{1,2}$, Ethirajan Sukumar ${ }^{1}$, Kashinath RT $^{3 *}$ \\ ${ }^{1}$ Department of Research, Saveetha Institute of Medical and Technical Science (Deemed University), Thandalam, \\ Chennai, India \\ ${ }^{2}$ Department of Biochemistry, Subbaiah Institute of Medical Sciences, Purle, Shivamogga, India \\ ${ }^{3}$ R\&D Department, Subbaiah Institute of Medical Sciences, Purle, Shivamogga, India
}

\begin{abstract}
The garlic and its principle sulfur compound, diallyl disulphide (DADS) have been claimed to have hypoglycemic action and are beneficial in achieving glycemic control in diabetes mellitus (DM). The actual mechanism how the DADS regulates glucose level in DM is not clearly established though it is known that DADS do influence insulin action probably by improving insulin half-life. A study was undertaken to assess the influence of DADS on glucose utilization in isolated alloxan diabetic liver tissues and to compare DADS action with standard hypoglycemic drug, metformin. The study included four groups: group-1 (normal control liver tissues), group-2 (alloxan diabetic liver tissues), group-3 (Metformin exposed alloxan diabetic liver tissues) and group-4 (DADS exposed alloxan diabetic liver tissues). The liver tissues of groups 3 and 4 were incubated respectively with metformin $(4 \mathrm{mg} / \mathrm{g}$ liver) and DADS $\left(4 \mathrm{mg} / \mathrm{g}\right.$ liver) for one hour at $37^{\circ} \mathrm{C}$. The results showed significant raise $(\mathbf{p}<0.01)$ in glucose utilization and lactate production in group 4 liver tissues as compared to group 2 suggesting influence of DADS on the glucose utilization promotional effect of DADS which is quite comparable with metformin. The influence of glucose utilization by DADS is through increasing glycolysis in liver as well as its utilization through hexose mono phosphate (HMP) pathway as suggested by increased hexokinase (HK) and glucose-6-phosphate dehydrogenase (G6PD) activities. Study signifies the use of DADS as adjuvant therapy for glycemic control in DM.
\end{abstract}

Keywords: Diabetes mellitus, Alloxan, Diallyl disulphide (DADS), Glucose uptake, Lactate.

Accepted on August 22, 2018

\section{Introduction}

Diabetes mellitus (DM) is a chronic metabolic disorder due to either deficiency of insulin or subnormal function of insulin $[1,2]$. Glucose metabolism is primarily affected in DM as insulin is known to influence it in particular. Diabetic patients are prone to many diabetes induced life threatening complications such as neuropathy, retinopathy, nephropathy, cardiopathy and other micro or macro vascular complications $[3,4]$. Patients with uncontrolled blood glucose levels are particularly at high risk and consistent hyperglycemia plays an important role in the pathogenesis of diabetes induced complications [5]. Insulin, a peptide hormone which influences the glucose utilization by favoring action of various enzymes involved in glucose as well as glycogen metabolism [6,7]. Apart from insulin and other hypoglycemic agents, many herbal preparations have been tried to improve glucose utilization in DM [8-11]. Even the World Health Organization (WHO) has also recommended the evaluation of plants effectiveness in controlling rampant spreading of DM as we lack in safe modern drugs [12]. This has led to increasing demand for research on natural anti-diabetic products which produces minimal or no side effects [13]. Allium group of plants in general and garlic products in particular were proved to have beneficial effects in DM [14,15]. A modified disulphide, diacetodibutyl disulphide (DADBDS) been shown to produce significant hypoglycemic effects in alloxan diabetic rats [16]. Though it is known that garlic or one of its active principles, DADS as well as modified disulphide DADBDS may influence insulin action or increase insulin's half-life, the actual mechanism of action in alloxan diabetic animals is still obscure $[9,17]$. Hence a study was undertaken to establish the possible influence of DADS on glucose utilization in isolated alloxan diabetic liver tissues and to compare this action of DADS with metformin (Dimethylbiguanide), which is a common drug used for the treatment of type-2 DM [18,19]. 


\section{Materials and Methods}

\section{Chemicals}

DADS, metformin and alloxan were procured from Sigma Aldrich Chemicals (St. Louis, U.S.A.) and the remaining chemicals used were of analytical grade supplied from Merck Chemical Co. and HiMedia Laboratories Pvt. Ltd.

\section{Experimental animals}

Healthy male Wistar rats $(200 \pm 50 \mathrm{~g})$ were randomly selected from the Institutional Animal House facility and housed in polycarbonate cages under normal $12 \mathrm{~h}$ day-night cycle at temperature of $22 \pm 2^{\circ} \mathrm{C}$. The experiments were conducted as per the stipulations of CPCSEA under the supervision of Institutional Animal Ethics Committee (Permission No: BMCH/IAEC/04 Biochem/2015).

The selected rats were divided into four groups.

i. Group-1 (normal control $n=6$ ): Maintained on commercial rat feed (Amruth Rat Feed supplied by M/s. Pranav Agro Industries, Pune, India) and water was provided ad libitum for $30 \mathrm{~d}$.

ii. Groups 2-4 each containing 6 rats, were induced diabetes by administering a single intra peritoneal injection of a freshly prepared aqueous solution of alloxan monohydrate $(150 \mathrm{mg} / \mathrm{kg}$ b.w.) $[20,21]$ in normal saline to the overnight fasted rats. The onset of diabetes was monitored $48 \mathrm{~h}$ after alloxan injection by using urine strips (Mission urine strips) and the animals that tested positive for glucose for 3 consecutive days were considered as diabetic rats to be employed in the present study. Later these alloxan induced diabetic rats (Groups 2-4) were maintained on stock lab diet and water ad libitum for $30 \mathrm{~d}$.

After the stipulated period of $30 \mathrm{~d}$, each animal of all the groups were separately weighed and body weight was noted. The animals were anesthetized (anesthetic ether) and sacrificed. They were dissected immediately and liver tissue was procured, blotted slightly and liver weight was recorded. The liver tissues of each rat were suspended separately in cold phosphate buffer saline $\mathrm{pH} 7.4$ (PBS). The suspended each liver tissue was separately cut into small pieces of $0.5 \mathrm{~g}$ each $[22,23]$. These liver tissues were employed in the present work. The liver tissues of group 1 are employed as normal control liver, group 2 liver tissues were employed as alloxan diabetic liver, group 3 liver tissues employed for metformin exposure (4 $\mathrm{mg} / \mathrm{g}$ liver) and group 4 liver tissues were employed for DADS exposure (4 mg/g liver) studies [24].

\section{Experimental design}

Glycogen content and glycogen breakdown studies: The glycogen content and glycogen breakdown in groups 1-4 was estimated using $0.5 \mathrm{~g}$ of each liver tissue of these groups separately. The glycogen released by heating with strong alkali was precipitated with the addition of ethanol, sodium sulphate was used as a co-precipitant to give a quantitative yield of glycogen. The polysaccharide is then hydrolyzed with acid and the glucose released was estimated [25]. The amount of glycogen utilized was calculated by assessing the difference in glycogen content in pre and post incubation liver tissues.

Glucose utilization studies [23]: The glucose [26], lactate [27] contents of both pre and post incubated liver samples of groups 1-4 were estimated as narrated below.

Half gram $(0.5 \mathrm{~g})$ of groups 1-4 liver tissues were taken separately in incubation tubes and $1 \mathrm{ml}$ of freshly prepared buffered glucose solution $(0.1 \mathrm{~g}(\%)$ glucose in phosphate buffer, $\mathrm{pH}$ 7.4) was added to all the tubes. For tube containing liver tissue of group $310 \mu \mathrm{l}$ metformin ( $4 \mathrm{mg} / \mathrm{g}$ liver) and for the tube containing liver tissue of group $410 \mu \mathrm{l}$ DADS $(4 \mathrm{mg} / \mathrm{g}$ liver) was respectively added. To all the tubes $3.5 \mathrm{ml}$ of $10 \%$ TCA (trichloro acetic acid) was added and the tubes were allowed to stand at room temperature for $15 \mathrm{~min}$ for protein precipitation. Then the contents of all the four tubes were thoroughly homogenized using Remi Homogenizer and centrifuged $(3000 \mathrm{rpm})$ for $5 \mathrm{~min}$. The clear supernatant obtained was employed for the estimation of glucose by Otoluidine method [26] and lactate by Barker and Summerson method after removing glucose and other interfering materials by the Van Slyke-Salkowski method of treatment with copper sulfate and calcium hydroxide [27]. The values obtained were considered as the pre-incubation values.

Similarly, for post-incubation levels of glucose and lactate, a $0.5 \mathrm{~g}$ each of groups 1-4 liver tissues were separately taken in incubation tubes and $1 \mathrm{ml}$ of freshly prepared buffered glucose solution $(0.1 \mathrm{~g} \%$ glucose in phosphate buffer, $\mathrm{pH}$ 7.4) was added to all the tubes. For tube containing liver tissue of group $310 \mu \mathrm{lmetformin}$ ( $4 \mathrm{mg} / \mathrm{g}$ liver) and for the tube liver tissue of group $410 \mu \mathrm{DADS}$ (4 mg/g liver) was respectively added. All the tubes were incubated at $37^{\circ} \mathrm{C}$ in a thermostatically regulated water bath for $60 \mathrm{~min}$. Later the tubes were processed to get the protein free supernatant as described above. The supernatants were employed for estimation of glucose [26] and lactate [27]. The values obtained were taken as post-incubation values.

Glucose utilized and lactate produced were calculated as follows:

The glucose that formed by liver glycogen breakdown during incubation period was taken into consideration in glucose utilization calculations.

1) Glucose utilization $/ \mathrm{h} / \mathrm{g}$ liver $=$ (Pre-incubation glucose level +glucose produced through glycogen breakdown-postincubation glucose level)

2) Lactate $\mathrm{produced} / \mathrm{h} / \mathrm{g}$ liver $=[($ Pre-incubation glucose level +glucose produced through glycogen breakdown)-Postincubation glucose level]

3) Estimation of enzyme activities (HK (EC: 2.7.1.1) [28] and G6PD (EC: 1.1.1.49) [29-31])

Half gram $(0.5 \mathrm{~g})$ each of groups 1-4 liver tissues were taken separately in clean dry test tubes containing $1.0 \mathrm{ml}$ phosphate buffer ( $\mathrm{pH}$ 7.4). For tube containing liver tissue of group 310 
$\mu l$ metformin ( $4 \mathrm{mg} / \mathrm{g}$ liver) and for the tube containing liver tissue of group $410 \mu \mathrm{l}$ DADS (4 mg/g liver) was respectively added. Then the contents were incubated for $60 \mathrm{~min}$ at $37^{\circ} \mathrm{C}$ in a thermostatically regulated water bath. At the end of the

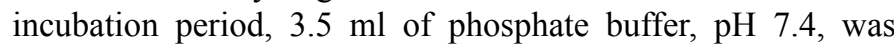
added and the contents were homogenized for $5 \mathrm{~min}$ and centrifuged for $5 \mathrm{~min}$ at $3000 \mathrm{rpm}$. The supernatant was employed for the estimations of the enzyme activities (HK and G6PD).

\section{Statistical evaluation}

The data was statistically analysed by one way ANOVA (Dunnet's multiple comparison test) using software GraphPad InStat (Version-3). The results were expressed as mean $\pm \mathrm{SEM}$ and values with $\mathrm{p}<0.05$ were considered significant.

\section{Results}

The results obtained in the present study are presented in Tables 1-4 as well as in Figure 1. Table 1 shows body weight, liver weight, Hepato-Somatic Index (HSI) and glucose produced through glycogen breakdown $/ \mathrm{h} / \mathrm{g}$ liver in normal control liver tissues (Group 1), in alloxan diabetic liver tissues (Group 2), in metformin exposed (4 mg/g liver) alloxan diabetic liver tissues (Group 3) and in DADS exposed $(4 \mathrm{mg} / \mathrm{g}$ liver) alloxan diabetic liver tissues (Group 4). Results shows increase in hepato-somatic index in groups 2 and 3 and in group 4 as compared to group 1. It can be inferred from the table that the glycogen breakdown in group 2 is significantly $(p<0.01)$ lowered when compared to group 1 whereas raise was observed in groups 3 and 4 as compared to group 1 indicating that influence of metformin and DADS on glycogen breakdown.

Table 2 narrates the glucose utilization and percentage of glucose utilization in groups 1-4. It is evident from the table that a significant decrease in glucose utilization $(p<0.01)$ seen in group 2 as compared to group 1, whereas an increase in glucose utilization was observed in groups 3 and 4 as compared to group 2. The increase in glucose utilization in group 4 is significant $(\mathrm{p}<0.01)$ as compared to group 2 suggesting DADS influence on glucose utilization in alloxan diabetic liver tissues and this influence is more as compared to group 3 (metformin exposed).

Table 3 gives the amount of lactate produced ( $\mathrm{mg} / \mathrm{g}$ liver) in all the four groups. The results indicate a significant decrease in lactate production $(\mathrm{p}<0.01)$ in group 2 as compared to group 1 , whereas a significant raise $(\mathrm{p}<0.01)$ in groups 3 and 4 as compared to group 2, suggesting both metformin and DADS possibly influence glucose utilization through glycolytic pathway and the results indicate that DADS is equally good in influencing the glucose utilization through glycolytic pathway in liver, as compared to metformin.

Table 4 shows enzyme activities of HK and G6PD in liver tissues of all the groups. It is clear that there is significant $(\mathrm{p}<0.01)$ decrease in HK and G6PD activities in group 2 as compared to group 1 , whereas there is significant $(\mathrm{p}<0.01)$ increase in hexokinase and G6PD activities in groups 3 and 4 as compared to group 2. Thus indicating an influencing effect of Metformin and DADS on HK as well as G6PD activities.

Figure 1 depicts the graphical representation of percentage of glucose utilization, percentage of lactate formation and the Hexokinase activity in groups 1-4 liver tissues. It is clear from the figure that DADS has a positive influence on the glucose utilization as well as lactate formation which is quite comparable with standard hypoglycemic drug, Metformin. This further suggests that DADS do favor glucose utilization in alloxan diabetic liver by promoting glucose utilization through glycolysis which is evidenced by a significant raise in HK activity (Figure 1 and Table 4).

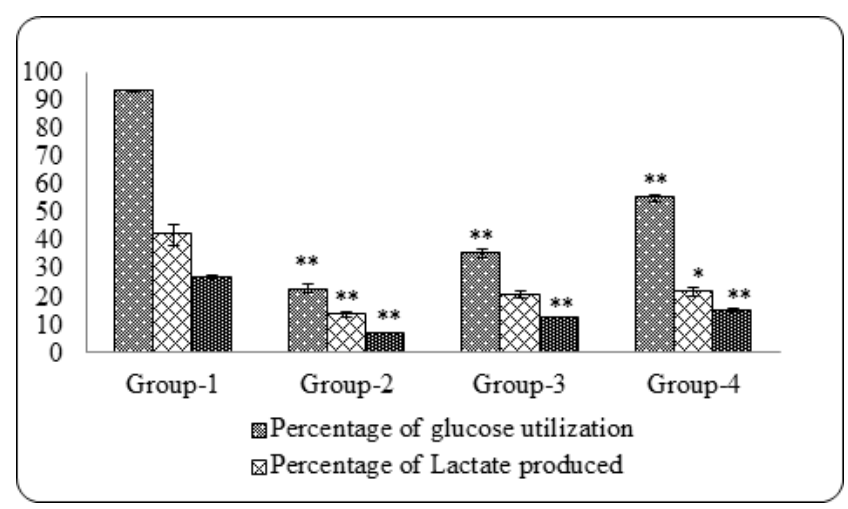

Figure 1. Shows percentage of glucose utilization $(\mathrm{mg} / \mathrm{g}$ liver/h), percentage of lactate produced $(\mathrm{mg} / \mathrm{g}$ liver $/ \mathrm{h})$ and $H K$ activity in groups 1-4. Data represented in mean \pm SEM, ${ }^{*} p<0.01,{ }^{* *} p<0.01$, alloxan diabetic liver tissues (Group-2) in comparison to normal control liver tissues (Group-1), metformin exposed (4 $\mathrm{mg} / \mathrm{g}$ liver) alloxan diabetic liver tissues (Group-3) and diallyl disulphide exposed (DADS $4 \mathrm{mg} / \mathrm{g}$ liver) alloxan diabetic liver tissues (Group 4) in comparison to alloxan diabetic liver tissues (Group 2).

Table 1. Shows body weight, liver weight and Hepato-Somatic Index (HSI) as well as the glucose produced by glycogen breakdown in isolated liver tissues.

\begin{tabular}{|c|c|c|c|c|c|c|}
\hline Groups & Body weight (g) & Liver weight (g) & HSI & $\begin{array}{l}\text { Pre incubation } \\
\text { glycogen } \quad(\mathrm{mg} / \mathrm{g} \\
\text { liver) }\end{array}$ & $\begin{array}{l}\text { Post incubation } \\
\text { glycogen } \quad(\mathrm{mg} / \mathrm{g} \\
\text { liver) }\end{array}$ & $\begin{array}{l}\text { Glucose produced from } \\
\text { glycogen (mg/g liver/h) }\end{array}$ \\
\hline Group 1 & $265.53 \pm 8.61$ & $6.5 \pm 0.17$ & $24.5 \pm 0.51$ & $93.5 \pm 0.32$ & $10.85 \pm 1.39$ & $82.31 \pm 3.26$ \\
\hline Group 2 & $220.83 \pm 8.20^{\star *}$ & $6.66 \pm 0.2$ & $30.34 \pm 1.00^{\star \star}$ & $15.81 \pm 0.37$ & $13.26 \pm 0.28$ & $2.55 \pm 0.21^{* *}$ \\
\hline Group 3 & $244.16 \pm 3.04$ & $6.46 \pm 0.39$ & $26.29 \pm 1.54$ & $17.31 \pm 0.2$ & $13.1 \pm 0.18$ & $4.07 \pm 0.29$ \\
\hline
\end{tabular}




\begin{tabular}{|c|c|c|c|c|c|c|}
\hline Group 4 & $235 \pm 4.27^{\star *}$ & $6.78 \pm 0.25$ & $28.85 \pm 0.91^{*}$ & $17.35 \pm 0.43$ & $13.25 \pm 0.22$ & $4.1 \pm 0.41$ \\
\hline \multicolumn{7}{|c|}{ HSI=Liver weight $(\mathrm{g}) /$ body weight $(\mathrm{kg})$. Data represented in mean $\pm \mathrm{SEM},{ }^{*} \mathrm{p}<0.05,{ }^{* *} \mathrm{p}<0.01$} \\
\hline \multicolumn{7}{|c|}{ Table 2. Glucose utilization by liver tissues. } \\
\hline Groups & $\begin{array}{l}\text { Glucose content } \\
\text { (mg/g liver) }\end{array}$ & $\begin{array}{l}\text { Glucose produced } \\
\text { from glycogen }(\mathrm{mg} / \mathrm{g} \\
\text { liver })\end{array}$ & $\begin{array}{l}\text { Pre } \\
\text { glucose level }(\mathrm{mg} / \mathrm{g} \\
\text { liver) }\end{array}$ & $\begin{array}{l}\text { Post incubation glucose } \\
\text { level (mg/g liver) }\end{array}$ & $\begin{array}{l}\text { Glucose utilized } \\
\text { (mg/g liver/h) }\end{array}$ & $\begin{array}{l}\text { Percentage of glucose } \\
\text { utilization }(\mathrm{mg} / \mathrm{g} \\
\text { liver/h) }\end{array}$ \\
\hline Group 1 & $13.8 \pm 1.155$ & $82.31 \pm 7.991$ & $96.18 \pm 3.11$ & $6.30 \pm 0.20$ & $89.88 \pm 3.21$ & $93.39 \pm 0.36$ \\
\hline Group 2 & $14.0 \pm 0.273$ & $2.5 \pm 0.532$ & $17.36 \pm 0.24$ & $13.41 \pm 0.36$ & $3.95 \pm 0.28^{* *}$ & $22.75 \pm 1.58^{\star *}$ \\
\hline Group 3 & $13.41 \pm 1.02$ & $4.07 \pm 0.56$ & $17.49 \pm 0.51$ & $11.30 \pm 0.54$ & $6.19 \pm 0.22$ & $35.52 \pm 1.56^{\star *}$ \\
\hline Group 4 & $13.3 \pm 0.505$ & $4.1 \pm 1.028$ & $17.26 \pm 0.08$ & $7.71 \pm 0.21$ & $9.53 \pm 0.21^{*}$ & $55.21 \pm 1.23^{* *}$ \\
\hline
\end{tabular}

Data represented in mean \pm SEM, ${ }^{*} p<0.05,{ }^{* *} p<0.01$.

Table 3. Lactate production in liver tissues.

\begin{tabular}{|c|c|c|c|c|c|}
\hline Groups & Pre incubation lactate content (mg/g liver) & $\begin{array}{l}\text { Post incubation } \\
\text { (mg/g liver) }\end{array}$ & lactate & Lactate produced (mg/g liver/h) & $\begin{array}{l}\text { Percentage of lactate } \\
\text { produced }(\mathrm{mg} / \mathrm{g} \text { liver } / \mathrm{h})\end{array}$ \\
\hline Group 1 & $0.19 \pm 0.005$ & $0.27 \pm 0.005$ & & $0.08 \pm 0.005$ & $42.16 \pm 3.61$ \\
\hline Group 2 & $0.37 \pm 0.005$ & $0.42 \pm 0.004$ & & $0.05 \pm 0.002^{* *}$ & $13.51 \pm 0.83^{\star *}$ \\
\hline Group 3 & $0.36 \pm 0.003$ & $0.43 \pm 0.006$ & & $0.075 \pm 0.004^{\star *}$ & $20.71 \pm 1.13$ \\
\hline Group 4 & $0.37 \pm 0.006$ & $0.45 \pm 0.004$ & & $0.08 \pm 0.004^{\star *}$ & $21.71 \pm 1.45^{*}$ \\
\hline
\end{tabular}

Table 4. Hexokinase $(\mathrm{HK})$ and glucose 6 phosphate dehydrogenase (G6PD) enzyme activities.

\begin{tabular}{lll}
\hline Groups & HK in units & G6PD in units \\
\hline Group 1 & $27.13 \pm 0.78$ & $80.81 \pm 0.52$ \\
\hline Group 2 & $7.13 \pm 0.24^{* *}$ & $55.13 \pm 0.39^{* *}$ \\
\hline Group 3 & $12.60 \pm 0.08^{* *}$ & $65.40 \pm 0.30^{* *}$ \\
\hline Group 4 & $15.13 \pm 0.65^{* *}$ & $70.25 \pm 0.38^{* *}$ \\
\hline
\end{tabular}

Data represented in mean \pm SEM, ${ }^{* *} p<0.01$. Note: HK 1 unit $=1 \mathrm{m \mu} \mathrm{Mol}$ phosphate transferred/h/mg liver and G6PD 1 unit=amount of $\mathrm{NADPH}$ produced $/ \mathrm{min} / \mathrm{g}$ liver.

\section{Discussion}

In principle, any enzyme or protein having accessible thiol groups which are essential for its activity is capable of yielding itself to changes in cellular thiol-disulfide ratio thus making such enzymes or proteins for easy modulation [32]. This cellular thiol-disulfide balance can be altered by treating animals or isolated tissues with readily absorbable thiols or disulfides [32-34]. It is known that many enzymes particularly glycolytic kinases are thiol enzymes and are easily affected by changes in thiol-disufide balance [32,35-38]. In DM the tissue total-thiol concentration is reduced [8] there by creating disturbances in various metabolic pathways especially the pathways of carbohydrate metabolism.
DADS is an aliphatic low molecular weight disulphide, similar to any other disulphide, may undergo a degradation to produce respective thiols in liver tissue cells in presence of NADPH/GSH dependent reductase [39-41].

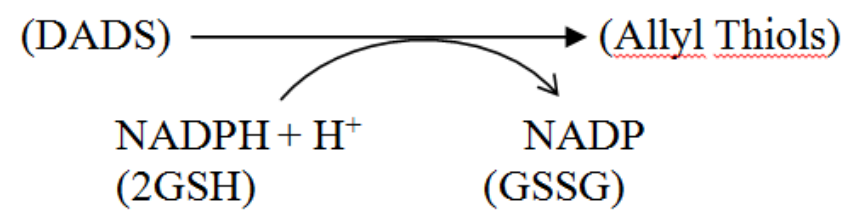

This increases the cellular availability of $\mathrm{NADP}^{+} / \mathrm{NAD}^{+}$, hence favor glucose utilization as it is known that NAD/NADH ratio do regulate cellular glucose utilization and a raised NAD level favors glucose utilization [39]. A raise in $\mathrm{NADP}^{+}$levels may facilitate glucose utilization through HMP pathway further favoring glucose utilization $[42,43]$ as the important enzymes of HMP pathway-G6PD and 6-phospho gluconic dehydrogenase are $\mathrm{NADP}^{+}$dependent. The results of the present study with respect to glucose utilization by liver tissues exposed to DADS (Group 4) showed a significant rise as compared to group 2 is consistent with the above statement and shows the glucose utilization promotional-effect of DADS in alloxan diabetic liver.

The thiols so produced as explained in the above reaction may alter the cellular thiol-disulphide ratio which is detrimental for the functioning of thiol enzymes involved in glucose metabolism. It is known that low molecular weight thiols 
influence the activity of certain glycolytic enzymes thus favor glucose utilization [44]. The allyl thiols, produced by the degradation of DADS are being low molecular weight thiols might have influenced glycolytic enzymes like HK, phospofructokinase and pyruvate kinase [32,35,38], hence more glucose is utilized through glycolytic pathway in group 4 liver tissues. This is further evidenced by increased lactate production in group 4 liver tissues as compared to group 2 liver tissues (Table 3) indicating clearly the role of DADS in increasing glycolytic utilization of glucose.

DADS, similar to any other disulphide may undergo sulphydryl exchange reaction with cellular thiol proteins or thiol enzymes as depicted below $[45,46]$.

\section{RSSR+enzyme-SH $\rightarrow$ RSH+enzyme-S-S-R}

The Protein Tyrosine Phosphatases (PTP's), which are involved in end regulation insulin receptor triggered PTP's and Insulin Receptor Substrates (IRS), are thiol enzymes [44] and DADS might undergo a similar sulfhydryl exchange reaction (as mentioned above) with PTP's thereby inhibiting their action, hence PTP's and other IRS may remain in the functioning state thereby enhancing glucose uptake and utilization.

DADS has been shown as a protein glycation inhibitor [13] may prevent insulin glycation, thereby enhances the life span of insulin and such an enhancement in group 4 may influence insulin life span, hence may cause increase glucose utilization and lactate production as observed in the present study. The raise in lactate production in group 4 which is in agreement with earlier studies [23] and is due to enhancement of glucose utilization through glycolytic pathway in group 4 as compared to group 2, which is further evidenced by a proportional raise in activity of HK, which is supposed to be a thiol enzyme and the thiols produced by degradation of DADS may influence its activity.

Further a significant raise in percentage of glucose utilization $(\mathrm{mg} / \mathrm{g}$ liver/h) as well as percentage of lactate production (mg/g liver/h) is observed in group 4 as compared to group 2 . Suggesting that there is a positive influence by DADS on over all glucose utilization in group 4.

Metformin a commonly employed anti-diabetic drug was taken as standard to compare as DADS glucose-utilizationpromotional effects in alloxan diabetic liver tissues. In the present studies it is confirmed that DADS influence on glucose-utilization in alloxan diabetic liver and as depicted in the Figure 1, is quite comparable with the action of standard drug, metformin.

\section{Conclusion}

It can be concluded by the results obtained in the present studies that DADS at the dosage employed influenced total liver glucose utilization by improving glucose breakdown through glycolytic pathway as well as through HMP pathway suggesting its possible utility as an adjuvant hypoglycemic substance in diabetic condition. However, a detailed study with different dosages and a systematic clinical approach can throw further light on DADS use in DM.

\section{Acknowledgement}

The authors are indebted to the authorities of Saveetha University, Chennai and Subbaiah Institute of Medical Sciences, Shivamogga for the encouragement, facilities and support.

\section{Conflicting Interest}

The authors have no conflict of interest.

\section{References}

1. American Diabetes Association. Diagnosis and classification of diabetes mellitus. Diabetes Care 2010; 33: 62-69.

2. Altan VM. The pharmacology of diabetic complications. Curr Med Chem 2003; 10: 1317-1327.

3. American Diabetes Association. Diagnosis and classification of diabetes mellitus. Diabetes Care 2014; 37: 81-90.

4. Fowler MJ. Microvascular and macrovascular complications of diabetes. Clin Diab 2008; 26: 77-82.

5. UK Prospective Diabetes Study (UKPDS) Group. Intensive blood-glucose control with sulphonylureas or insulin compared with conventional treatment and risk of complications in patients with type 2 diabetes (UKPDS 33). Lancet 1998; 352: 837-853.

6. Gold AH. The effect of diabetes and insulin on liver glycogen synthetase activation. J Biol Chem 1970; 245: 903-905.

7. Ortmeyer HK, Bodkin NL, Barbara $\mathrm{CH}$. Insulin regulates liver glycogen synthase and glycogen phosphorylase activity reciprocally in rhesus monkeys. Am J Physiol Endocrinol Met 1997; 272: 133-138.

8. Brahmachari HD, Augusti KT. Orally effective hypoglycaemic agents from plants. J Pharmacy Pharm 1962; 14: 254-255.

9. Kumari K, Mathew BC, Augusti KT. Antidiabetic and hypolipidemic effects of S-methyl cysteine sulfoxide isolated from Allium cepa Linn. Ind J Biochem Biophy 1995; 32: 49-54.

10. Augusti KT, Mathew PT. Effect of long-term feeding of the aqueous extracts of onion (Allium cepa Linn.) and garlic (Allium sativum Linn.) on normal rats. Indian J Exp Biol 1973; 11: 239-241.

11. Mathew PT, Augusti KT. Studies on the effect of allicin (diallyl disulphide-oxide) on alloxan diabetes. I. Hypoglycaemic action and enhancement of serum insulin effect and glycogen synthesis. Ind J Biochem Biophy 1973; 10: 209-212.

12. Day C. Traditional plant treatments for diabetes mellitus: pharmaceutical foods. British J Nutr 1998; 80: 5-6. 
13. El-Gamal EK. Therapeutic benefits of garlic against alloxan-induced diabetic in rats. JMSCR 2017; 5: 17445-17453.

14. Aggarwal KC. Therapeutic uses of garlic. Ind J Expt Biol 1996; 11: 239-241.

15. Augusti KT. Therapeutic values of onion (Allium cepa L.) and garlic (Allium sativum L.). Ind J Exp Biol 1996; 34: 634-640.

16. Joseph PK, Kasinath RT. Hypoglycemic and hypolipidemic effects of diacetodibutyl disulphide. Indian J Clin Biochem 2000; 15: 68-75.

17. Augusti KT. Studies on the effects of a hypoglycemic principle from Allium Cepa Linn. Indian J Med Res 1973; 61: 1066-1071.

18. Bailey CJ. Metformin revisited: its actions and indications for use. Diabet Med 1988; 5: 315-320.

19. Bailey CJ, Nattrass M. Treatment-metformin. Baillieres Clin Endocrinol Metab 1988; 2: 455-476.

20. Szkudelski T. The mechanism of alloxan and streptozotocin action in B cells of the rat pancreas. Physiol Res 2001; 50: 537-546.

21. Chougale AD, Panaskar SN, Gurao PM, Arvindekar AU. Optimization of alloxan dose is essential to induce stable diabetes for prolonged period. Asian J Biochem 2007; 2: 402-408.

22. Renold AE, Teng CT, Nesbett FB, Hastings AB. Studies on carbohydrate metabolism in rat liver slices. 2. The effect of fasting and of hormonal deficiencies. J Biol Chem 1953; 204: 533-546.

23. Vickram, Divya D, Raiker VG, Kashinath RT. Effect of thiopropanol on glucose utilization in alloxan diabetic rat liver. GJMR 2011; 11: 25-30.

24. Goudappala P, Sukumar E, Kashinath RT. Influence of diallyldisulphide on glycogen breakdown in alloxan diabetic liver. IOSR JDMS 2017; 16: 30-32.

25. $\mathrm{Mu} \mathrm{P}$, Plummer DT. Introduction to practical biochemistry. III-Edn Chapt-9 Carbohydrates. The isolation \& assay of glycogen from the liver \& skeletal muscle of rats. Tata McGraw-Hill Educ 1988; 182-184.

26. Cannon DC, Henry R, Winkelman JW. Clinical chemistry: principles and technics (2nd Edn.). Carbohydrates. Harper Row, Hagerstown Md 1974; 1285-1289.

27. Barker S. Lactic acid estimation. HawkS Physilogical Chemistry (14th Edn.). Blood Analysis 1965; 1102-1105.

28. Crane RK, Sols A. Animal tissue hexokinases: (Soluble and particulate forms) hexose+ATP? Hexose-6-P+ ADP 1955; 277-281.

29. Beutler E. Red cell metabolism. A manual of biochemical methods. Glucose-6-phosphate dehydrogenase. Grune Stratton $1975 ; 62-64$

30. Gross RT, Hurwitz RE, Marks PA. An hereditary enzymatic defect in erythrocyte metabolism: glucose-6phosphage dehydrogenase deficiency. J Clin Invest 1958; 37: 1176-1184.
31. Moss DW, Kachmar JF. Enzymes, in fundamentals of clinical chemistry. Saunders Philadelphia 1976; 666-672.

32. Ziegler DM. Role of reversible oxidation-reduction of enzyme thiols-disulfides in metabolic regulation. Ann Rev Biochem 1985; 54: 305-329.

33. Eldjarn L, Nygaard O. Cysteamine-cystamine: intestinal absorption, distribution among various organs and excretion. Arch Int de Physiol et de Biochimie 1954; 62: 476-486.

34. Mondovi B, Tentori L, De Marco C, Cavallini D. Distribution of cystamine-35S in the sub-cellular particles of the organs of the rat. Int J Rad Biol Relat Stud Phys Chem Med 1962; 4: 371-378.

35. Froede HC, Geraci G, Mansour TE. Studies on heart Phosphofructokinase thiol groups and their relationship to activity. J Biol Chem 1968; 243: 6021-6029.

36. Gilbert HF. Biological disulfides: the third messenger? Modulation of phosphofructokinase activity by thiol/ disulfide exchange. J Biol Chem 1982; 257: 12086-12091.

37. Nesbakken R, Eldjarn L. The inhibition of hexokinase by disulphides. Biochem J 1963; 87: 526-532.

38. Ondarza RN. Enzyme regulation by biological disulfides. Biosci Rep 1989; 9: 593-604.

39. Gibson G, Blass JP. A relation between $(\mathrm{NAD}+) /(\mathrm{NADH})$ potentials and glucose utilization in rat brain slices. J Biol Chem 1976; 251: 4127-4130.

40. Singh R, Whitesides GM, Patai S, Rappoport Z. Chemistry of sulphur-containing functional groups. John Wiley Sons Ltd. 1993; 634-658.

41. Black S. Reduction of sulfoxide and disulfides. Meth Enzymol 1962; 5: 992-998.

42. Lavis VR, Williams RH. Studies of the insulin-like actions of thiols upon isolated fat cells. J Biol Chem 1970; 245: 23-31.

43. Goko H, Takashima S, Kawamuro A, Matsuoka A. Insulin-like effects of dithiothreitol on isolated rat adipocytes. Biochem J 1981; 200: 425-428.

44. Goldstein BJ, Mahadev K, Wu X. Redox paradox: insulin action is facilitated by insulin-stimulated reactive oxygen species with multiple potential signaling targets. Diabetes 2005; 54: 311-321.

45. Adamu I, Joseph PK, Augusti KT. Hypolipidemic action of onion and garlic unsaturated oils in sucrose fed rats over a two-month period. Experientia 1982; 38: 899-901.

46. Augusti KT. Hypocholesterolaemic effect of garlic, Allium sativum Linn. Indian J Exp Biol 1977; 15: 489-490.

\section{*Correspondence to}

Kashinath RT

R\&D Department

Subbaiah Institute of Medical Sciences

India 